\title{
Effects of reduced salinity on the rates of photosyn- thesis and respiration in the hermatypic corals Porites lutea and Pocillopora damicornis
}

\author{
F. Moberg ${ }^{1, *, * *}$, M. Nyström ${ }^{1, * *}$, N. Kautsky ${ }^{1}$, M. Tedengren ${ }^{1}$, P. Jarayabhand ${ }^{2}$ \\ 'Dept of Systems Ecology, Stockholm University, S-106 91 Stockholm, Sweden \\ ${ }^{2}$ Dept of Marine Science, Faculty of Science, Chulalongkorn University, Bangkok 10330, Thailand
}

\begin{abstract}
This paper deals with sublethal salinity stress on reef building corals in the Inner Gulf of Thailand. Maximum photosynthetic and respiratory rates were measured in Porites Iutea and Pocillopora damicornis as changes in dissolved oxygen levels per hour and the gross production to respiration ratio (Pg:R) calculated. $P g: R$ ratios were significantly lowered in both species when exposed to sudden salinity drops from ambient $30 \%$ to 20 and $10 \%$, but $P$. lutea was less affected. Photosynthetic rates were lowered in proportion to the salinity reductions in both species, whereas respiration rates were either slightly decreased or unaltered. When calculating the $P g: R$ ratios on a $24 \mathrm{~h}$ basis both species displayed values below 1 , even at ambient salinity $(P$. lutea $0.71 \pm 0.04$ and $P$. damicornis $0.89 \pm 0.02$ ), thus indicating that they do not solely depend on internal primary production for their maintenance. In an experiment on the capacity of heterotrophic feeding with Artemia salina, $P$. damicornis showed a clearance rate 4 times higher than $P$. Iutea, indicating that $P$. damicornis may be more capable of compensating for a low $P g: R$ ratio by heterotrophic feeding
\end{abstract}

KEY WORDS: Coral · Porites lutea Pocillopora damicornis - Salinity $\cdot$ Photosynthesis $\cdot$ Respiration

\section{INTRODUCTION}

Reef corals were earlier considered to be dependent on a very narrow range of environmental conditions (Johannes 1975, Endean 1976, Loya 1976, Loya \& Rinkevich 1980). More recent results, however, suggest that corals are more adapted to physical stresses than was previously believed (Muthiga \& Szmant 1987, Harland \& Brown 1989, Grigg \& Dollar 1990, Coles 1992, Coles \& Jokiel 1992, Brown 1997b). Nonetheless, there is considerable variation in environmental tolerances among species which can have a major influence on the community structure within sites (Brown 1997a).

Since 4 of Thailand's 5 major rivers discharge into the Inner Gulf of Thailand the area receives an extensive freshwater load $\left(253 \times 10^{8} \mathrm{~m}^{3} \mathrm{yr}^{-1}\right.$; Menasveta et al. 1986). Therefore, during the rainy season the salin-

-E-mail: fredrikm@system.ecology.su.se

- Order of these 2 authors was determined by flipping a coin ity of the surface water decreases dramatically (Menasveta \& Hongskul 1988) and, according to our own field observations, shallow coral reefs can be exposed to salinities as low as $10 \%$ for short periods of time during low tide.

Despite the importance of salinity to physiological functions necessary for reef coral survival, relatively few studies have been made. Most of the literature is over 50 yr old, deals with field observations of lethal effects following rainstorms or groundwater intrusions and suggests that most species of reef corals are killed if salinity is reduced to $15-20 \%$ for $24 \mathrm{~h}$ or more (Edmondson 1928, Coles \& Jokiel 1992, Jokiel et al. 1993). Only a few authors have studied the effects of sublethal salinity changes (Muthiga \& Szmant 1987, Coles 1992). Corals, like most coelenterates, have few or no mechanisms for osmoregulation (Muthiga \& Szmant 1987), and thus a deviation from ambient salinity will affect their overall metabolism. In the long term, this stressed condition will imply decreased 
potential for growth, reproduction, and survival (Coles \& Jokiel 1992)

The objective of the present study was to determine the physiological responses of corals when exposed to lowered salinity. Coral photosynthesis and respiration were measured and changes in the gross production to respiration ratio ( $P g: R$ ratio) were used to determine the effects of salinity stress on coral metabolism (e.g McCloskey et al. 1978, Kinsey 1983, Edmunds \& Davies 1986, Muthiga \& Szmant 1987).

If the net input from the photosynthesis of the coral's symbiotic zooxanthellae is reduced (i.e. $P g: R$ ratio below 1) this must be compensated for by increased ingestion of organic carbon from heterotrophic feeding (Falkowski et al. 1990). The role of heterotrophic nutrition has been investigated by several authors, e.g Porter (1976), Edmunds \& Davies (1986), Bythell (1988) and Sorokin (1993), and the prevalent conclusion drawn from these studies is that the majority of hermatypic coral species are largely autotrophic. However, we hypothesise that heterotrophic feeding will be relatively more important in areas like the Inner Gulf of Thailand, where photosynthesis might be reduced due to turbidity and salinity stress. Accordingly, in order to estimate the relative capability of the corals to compensate for a low $P_{g}: R$ ratio by heterotrophic nutrition, the clearance rate was studied. The coral species investigated here were chosen for their dominance in the study area and because Pocillopora damicornis has been shown to be a superior competitor in the area under unstressed conditions compared to Porites lutea (Sakai et al. 1989).

\section{MATERIALS AND METHODS}

Study site. The present study was conducted in November 1994 at Angsila Marine Biological Research Station using coral specimens from the Khang Khao Island $\left(13^{\circ} 09^{\prime} \mathrm{N}, 100^{\circ} 48^{\prime} \mathrm{E}\right)$, in the Sichang Islands, Inner Gulf of Thailand. The massive coral Porites lutea is overwhelmingly dominant in the coral community, which is otherwise poorly developed with low diversity (Sakai et al. 1989).

Collection of corals. Corals were collected along the eastern coast of Khang Khao Island at $4 \mathrm{~m}$ depth (tidal range $\leq 3 \mathrm{~m}$ i Menasveta et al. 1986). Colonies of Porites lutea and Pocillopora damicornis were transported under reduced light and continuous aeration to the field station where they were placed in continuous-flow tanks. No significant temperature increase occurred during the transport. Corals used in the experiments were in good condition, and epiphytes and boring animals were absent or had been carefully removed.

Experimental design. Pieces of corals (a total of 27 replicates of each species, of approximately equal size, grown under similar light conditions) were placed in 5.35 l transparent cylindrical plastic experimental chambers equipped with submersible pumps (Whale ${ }^{\text {(i) }}$, supersub 881). The enclosures were placed in a cooling bath of continuously running seawater to minimise temperature fluctuations. A short-term experimental set-up was employed since salinity changes mostly occur rapidly in the study area (Nakano et al. in press) and because incubation in enclosures for more than a couple of hours without flushing may affect the corals severely and make interpretation of data unreliable (McCloskey et al. 1978, Sorokin 1993).

Physiological measurements. The net effect of the salinity change on coral metabolism was studied by calculating the gross production to respiration ratio $(P g: R)$. This ratio is a dimensionless estimate of the autotrophic capability of a community or an organism, and a ratio equal to or above 1 on a $24 \mathrm{~h}$ basis indicates self-maintenance (e.g. Odum \& Odum 1955, McCloskey et al. 1978, Kinsey 1983). It can be used in a short-term test to evaluate the effects of changes in physical parameters on the net metabolism of a photosynthetic organism (Johannes 1975, Lindblad et al. 1989, Coles \& Jokiel 1992, Sorokin 1993).

Net primary production and respiration were measured as changes in dissolved oxygen levels over $1 \mathrm{~h}$ under both light and dark conditions at 10,20 and 30\% salinity. The corals were acclimated in aerated flowthrough tanks at a specific salinity for $1.5 \mathrm{~h}$ before measurements were started (using filtered natural seawater diluted with pre-analysed filtered freshwater for the lower salinities). Readings were made every half hour with a polarographic oxygen electrode (Oximeter OXI 196). Oxygen saturation levels were maintained at $75 \%$ or above throughout the experiment. The pumps were run during measurements and also for $10 \mathrm{~s}$ every 15 min to avoid the build up of oxygen gradients in the enclosures and to create adequate water movement for exchange of materials at the tissue-water interface.

All oxygen production experiments were run outdoors under clear weather conditions between 10:00 and 14:00 h. Light intensities were recorded continuously with a Li Cor quantum sensor, placed adjacent to the experimental chambers, measuring photosynthetically active radiation. The relationship between the irradiance at the sensor and the irradiance in the chambers was determined after the experiments, and the continuously measured insolation actually experienced by the corals was calculated according to this relationship. Light intensities in the study were between 870 and $1060 \mu \mathrm{E} \mathrm{m}^{-2} \mathrm{~s}^{-1}$, which is approximately the same as in the study site at $4 \mathrm{~m}$ depth on a clear day (pers. obs.). Since these light intensities were above the light saturation level (approximately $500 \mu \mathrm{E} \mathrm{m}^{-2} \mathrm{~s}^{-1}$; Chalker et al. 1983) the production measured should be consid- 
ered as maximum net photosynthesis. To obtain the maximum gross production $(P g)$, respiration $(R)$ was added to the net production $(P n)$, assuming that constant respiration over the whole diurnal cycle, and the photosynthetic quotient (PQ) and respiratory quotient (RQ) are at approximate unity (McCloskey et al. 1978). The $P g: R$ ratios were then extrapolated on a $24 \mathrm{~h}$ basis using the light factor method (Kautsky 1995):

$$
P g: R_{(24)}=\frac{P g_{\Delta t} \times I_{24}}{R_{\Delta t} \times 24 \times I_{\Delta t}}
$$

where $P_{g_{\Delta t}}=$ gross production during the $1 \mathrm{~h}$ measurement $\left(\mu \mathrm{g} \mathrm{O} \mathrm{O}^{-1} \mathrm{~h}^{-1}\right) ; R_{\Delta t}=$ respiration during the $1 \mathrm{~h}$ measurement ( $\mu \mathrm{g} \mathrm{O}_{2} \mathrm{l}^{-1} \mathrm{~h}^{-1}$ ); $I_{\Delta t}=$ insolation during the incubation; and $I_{24}=$ the daily insolation.

Biomass determination. The use of $P g: R$ ratios eliminates the need for biomass determinations. However, in order to compare the $P g$ and $R$ values of the 2 coral species these data were normalised by means of a biomass determination. Such estimations are difficult in corals since the active living biomass is distributed in various amounts of calcium carbonate (McCloskey et al. 1978). Thus, several methods have been used in the literature, e.g. decalcification, chlorophyll extraction and ash-free dry weight measurement. In the present study the corals were dried at $70^{\circ} \mathrm{C}$ for $12 \mathrm{~h}$ and combusted at $430^{\circ} \mathrm{C}$ for $4 \mathrm{~h}$. The coral pieces were purposely selected, for same appearance, size and shape, and ash-free dry weight determination was therefore considered to give sufficiently accurate values

Heterotrophic feeding experiment. The heterotrophic feeding capacity was studied in a particle retention experiment, conducted at $30 \%$ salinity, using newly hatched nauplii $(0.7$ to $1.0 \mathrm{~mm})$ of the commercial brine shrimp Artemia salina. Dead coral colonies of equal size to the replicates (all $<500 \mathrm{~cm}^{3}$ ) were used as controls in order to estimate how many $A$. salina attached to the coral structure itself. The initial concentration averaged $7000 \mathrm{~A}$. salina per liter. For each replicate 3 samples of $10 \mathrm{ml}$ were taken initially and after $3 \mathrm{~h}$. The pumps were run while the samples were taken and also every $20 \mathrm{~min}$ for a period of $10 \mathrm{~s}$ to ensure that the nauplii were evenly distributed. The nauplii were counted by visual inspection and the biomass specific clearance rate (CR) was calculated according to the formula:

$$
\mathrm{CR}=\ln C_{0}-\ln C_{1} \times V \times \operatorname{Corr} \times B^{-1} \times t^{-1}
$$

where $C_{0}=$ initial concentration of $A$. salina; $C_{1}=$ final concentration of $A$ salina; $V=$ water volume (enclosure volume - coral volume); Corr. = correction factor (in percent) for $A$. salina adsorbed to the coral skeleton or the wall of the enclosure; $B=$ coral biomass in grams ash-free dry weight; $t$ = time between the readings.

Statistical analysis. Statistical comparisons between means of the $P g: R, P g: B$ and $R: B$ ratios for the 3 salinities were done using 1 -factor analysis of variance (ANOVA). All data were tested for homogeneity of variance using Cochran's test. When the variances were unequal, log-transformations were done and the success of each transformation was tested before running the ANOVA. The data was somewhat unbalanced, but, as Shaw \& Mitchell-Olds (1993) concluded, the effect of unbalanced data on single factor ANOVA is negligible. Where the 1-factor ANOVA showed significant differences, a multiple comparison of means was conducted using the Student-Newman-Keuls test.

\section{RESULTS}

\section{$P g: R$ ratio}

Physiological measurements showed that $P g: R$ ratios were lowered in both Porites lutea and Pocillopora damicornis when salinity was reduced (Fig. 1, Tables 1 $\& 2$ ), indicating that both species were stressed by the sudden salinity drop. The $P g: R$ ratio in $P$. damicornis decreased more rapidly than in $P$. lutea, implying that $P$. damicornis is more sensitive to decreased salinity (the slopes of the regression lines in Fig. 1 were significantly different, $\hat{\beta}_{2}-\hat{\beta}_{1}=0.0153 \pm 0.0037 Z_{0005}, \mathrm{p}<$ 0.01 )

Table 1. Porites lutea and Pocillopora damicornis. Data from the physiological measurements. Gross production (Pg), respiration $(R)$ and biomass $(B)$ in corals calculated $\mathrm{g}^{-1}$ ash-free dry weight (AFDW). SE of means within parentheses

\begin{tabular}{|lccccc|}
\hline Species & $\begin{array}{c}\text { Salinity } \\
(\% \mathrm{~m})\end{array}$ & $\begin{array}{c}P g: R \\
\left(\mathrm{~h}^{-1}\right)\end{array}$ & $\begin{array}{c}P_{g}: B \\
\left(\mu g \mathrm{O}_{2} \mathrm{~h}^{-1}\right)\end{array}$ & $\begin{array}{c}R: B \\
\left(\mu g \mathrm{O}_{2} \mathrm{~h}^{-1}\right)\end{array}$ & $\begin{array}{c}P g: R \\
\left(\mathrm{~d}^{-1}\right)\end{array}$ \\
\hline Porites lutea & 30 & $2.34( \pm 0.13)$ & $0.98( \pm 0.21)$ & $0.42( \pm 0.09)$ & $0.71( \pm 0.04)$ \\
& 20 & $1.75( \pm 0.13)$ & $0.49( \pm 0.07)$ & $0.29( \pm 0.05)$ & $0.53( \pm 0.04)$ \\
Pocillopora damicornis & 10 & $1.12( \pm 0.07)$ & $0.17( \pm 0.03)$ & $0.15( \pm 0.02)$ & $0.34( \pm 0.02)$ \\
& 30 & $2.92( \pm 0.07)$ & $3.78( \pm 0.27)$ & $1.29( \pm 0.08)$ & $0.89( \pm 0.02)$ \\
& 20 & $1.75( \pm 0.16)$ & $1.41( \pm 0.16)$ & $0.80( \pm 0.06)$ & $0.53( \pm 0.05)$ \\
& 10 & $0.77( \pm 0.08)$ & $0.55( \pm 0.14)$ & $0.69( \pm 0.12)$ & $0.23( \pm 0.03)$ \\
\end{tabular}




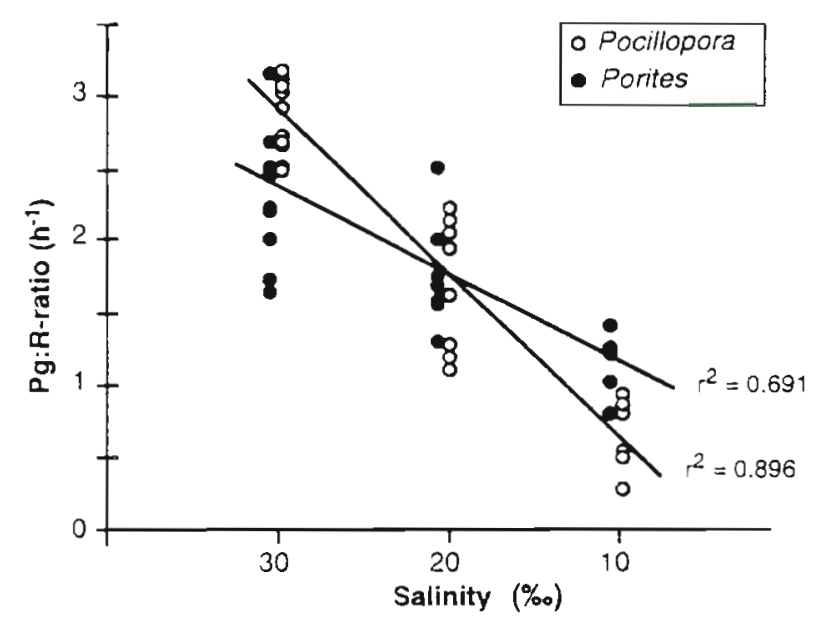

Fig. 1 Porites lutea and Pocillopora damicornis. Regression lines showing the correlation between $P g: R$ ratios per hour and salinity. $P g: R$ ratios decreased in both species when salinity was reduced. The slopes of the 2 lines were significantly different, $\hat{\beta}_{2}-\hat{\beta}_{1}=0.0153 \pm 0.0037 Z_{0005}(p<0.01)$. Coefficients of determination for $P$. Iutea $\mathrm{r}^{2}=0.691(t=7.47, \mathrm{df}=25, \mathrm{p} \ll$ $0.001)$; $P$. damicornis $\mathrm{r}^{2}=0.896(t=14.68, \mathrm{~d} f=25, \mathrm{p} \ll 0.001)$. For further statistical comparison see Table 2. Numbers of replicates: P. lutea $n(30 \%)=11, n(20 \%)=8, n(10 \%)=8$; P. damicornis $\mathrm{n}(30 \%)=12, \mathrm{n}(20 \%)=8, \mathrm{n}(10 \%)=7$

\section{$P g: B$ ratio}

The gross production per unit biomass decreased significantly in proportion to the salinity reductions for both Porites lutea and Pocillopora damicornis. However, $P$. damicornis showed a larger relative decrease when salinity was reduced (Fig. 2, Tables $1 \& 2$ ).

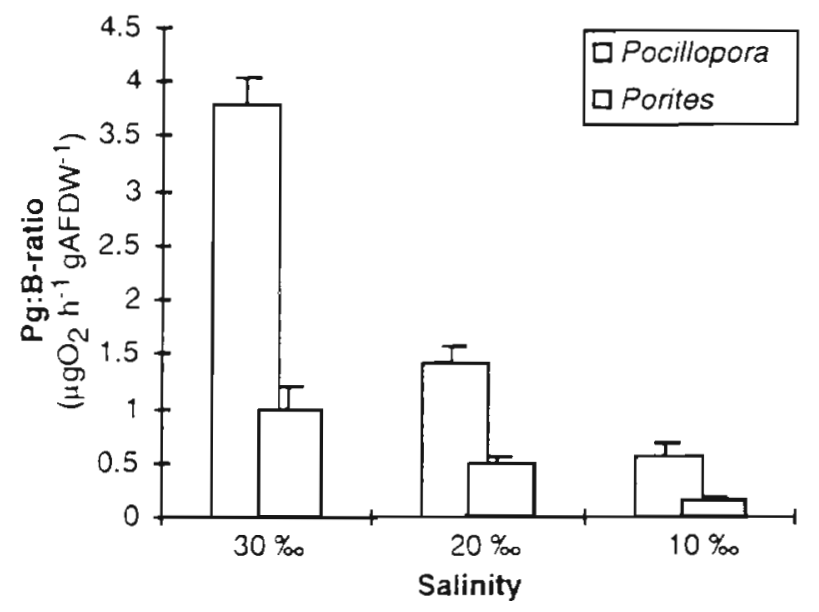

Fig. 2. Porites lutea and Pocillopora damicornis. Gross production to biomass ratios (Pg:B ratios) + SE per hour at 3 different salinities. $P g: B$ ratio decreased for both species when salinity was reduced. For statistical comparison see Table 2. Numbers of replicates are the same as in Fig. 1

\section{$R: B$ ratio}

Porites lutea displayed a significant decrease in $R: B$ ratio when salinity was reduced from 30 to $10 \%$ and from 20 to $10 \%$. However, no significant change was measured between 30 and $20 \%$. Pocillopora damicor$n i s$, on the other hand, lowered its $R: B$ ratio significantly between salinity changes from 30 to $10 \%$ as well as from 30 to $20 \%$, whereas a decrease from 20 to $10 \%$ was not significant (Fig. 3, Tables $1 \& 2$ )

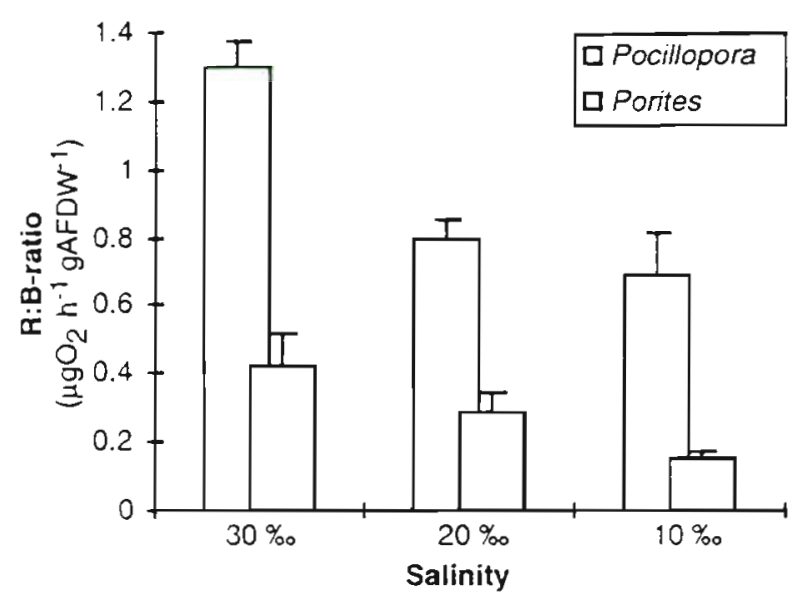

Fig. 3. Porites lutea and Pocillopora damicornis. Respiration to biomass ratios $(R: B$ ratios $)+$ SE per hour at 3 different salinities. In $P$. lutea respiration was lowered with salinity between 30 and $10 \%$, although the decrease between 30 and $20 \%$ was not significant (Student-Newman-Keuls, crit. diff. $=0.217$ and diff. $=0.136, p>0.05$ ). Respiration in $P$. damicornis was lowered between 30 and $20 \%$ but not between 20 and $10 \%$ (Student-Newman-Keuls, $p \gg 0.05$ ). For further statistical comparison see Table 2 . Numbers of replicates are the same as in Fig. 1

\section{Heterotrophic feeding}

The heterotrophic feeding experiment, conducted at $30 \%$ salinity, indicates that Pocillopora damicornis is more efficient than Porites lulea in consuming zooplankton within the size range used here. The clearance rate for $P$. damicornis was more than 4 times larger than for $P$. lutea $\left(0.24 \pm 0.086 \mathrm{l} \mathrm{h}^{-1} \mathrm{~g}^{-1}\right.$ biomass compared to $0.05 \pm 0.0191 \mathrm{~h}^{-1} \mathrm{~g}^{-1}$ ) (Fig. 4).

\section{DISCUSSION}

The present study did not intend to separate the responses of the coral polyps and their symbiotic zooxanthellae, but rather to investigate the combined physiological response of both the animal and algae. 
Table 2. Porites lutea and Pocillopora damicornis. Significance levels of the statistical analysis of means for the 3 physiological ratios at 30,20 and $10 \%$ salinity. Comparisons done within each species. One-factor ANOVA, log transformed values when needed, and multiple comparisons of means conducted using the Student-Newman-Keuls test. ns: not significant. $p<0.05, \cdots p<0.01$

\begin{tabular}{|c|c|c|c|c|}
\hline Species & & \multicolumn{2}{|c|}{ Salinity $(\%)$} & 30 \\
\hline \multirow[t]{6}{*}{ Porites lutea } & $P g: R$ & 10 & $"$ & $\cdots$ \\
\hline & & 20 & - & $\cdots$ \\
\hline & $P g: B$ & 10 & $\cdots$ & $\cdots$ \\
\hline & & 20 & - & $\cdot$ \\
\hline & $R: B$ & 10 & $\cdot$ & - \\
\hline & & 20 & - & ns \\
\hline \multirow[t]{6}{*}{ Pocillopora damicornis } & $P g: R$ & 10 & $\cdot \cdot$ & $\cdot \cdot$ \\
\hline & & 20 & - & $\cdots$ \\
\hline & $P g: B$ & 10 & .. & $\because$ \\
\hline & & 20 & - & $\cdots$ \\
\hline & $R: B$ & 10 & ns & " \\
\hline & & 20 & - & $\cdot \cdot$ \\
\hline
\end{tabular}

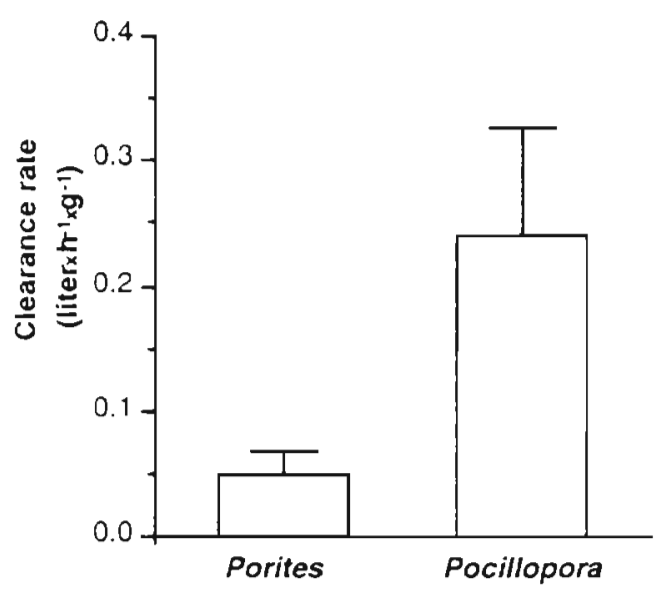

Fig. 4. Clearance rate + SE for Porites lutea $\left(0.05 \pm 0.019 \mathrm{l} \mathrm{h}^{-1}\right.$ $\left.\mathrm{g}^{-1} \mathrm{AFDW}\right)$ and Pocillopora damicornis $\left(0.24 \pm 0.086 \mathrm{l} \mathrm{h}^{-1} \mathrm{~g}^{-1}\right)$ at $30 \%$ salinity on Artemia salina nauplii

Such an approach implies that the metabolic activity of consumers, such as heterotrophic bacteria in the secreted mucus of corals (Segel \& Ducklow 1982), is included in the $P g: R$ ratio measurements.

Since salinity reductions often occur very rapidly, generally a few hours during low tide and extreme rainfall, we argue that a short-term stress study was appropriate. The sudden salinity reductions from ambient to 20 and $10 \%$ resulted in a significant decline in $P g: R$ ratios in both studied species, but Pocillopora damicornis showed a more marked response than Porites lutea when considering a range of salinities between 30 and $10 \%$. Thus, we believe that the former species should be regarded as more sensitive to a sudden drop in salinity. This conforms with several other studies indicating that $P$. damicornis is more stenohaline than most other corals and Porites is among the least sensitive to salinity changes (Edmondson 1928, Coles 1992, Coles \& Jokiel 1992, Jokiel et al. 1993, Nakano et al. in press).

Photosynthetic rates ( $P g: B$ ratios) were diminished in both coral species when salinity was reduced below ambient levels, but Pocillopora damicornis was slightly more affected. However, reduced photosynthesis was also accompanied by a decreased respiratory rate for both species. Similar physiological responses to sudden salinity drops were observed by Muthiga \& Szmant (1987) in Siderastrea siderea, and, according to Vernberg \& Vernberg (1972), a reduction in respiratory rate is a typical adaptive response to salinity stress. Lowering of the respiration rate entails decreased metabolic costs for maintenance, which has been described as an important function in the cellular response to stress, that increases the capability of the organism to resist changes in the environment (Koehn \& Bayne 1989). Compared to P. damicornis, Porites lutea had a significantly greater ability to reduce respiratory costs when salinity dropped to $10 \%$. The respiration rate of $P$. damicornis was reduced when exposed to $20 \%$, whereas no further reduction was seen at $10 \%$, implying that $P$. damicornis is not able to adapt its metabolism to the same extent as $P$. lutea.

A possible reason for both the reduction in photosynthesis and respiration could be that corals contract their polyps in order to minimise contact with the low salinity water (Muthiga \& Szmant 1987). Contraction was actually observed in both species. This leads to reduced gas exchange and thus lowered respiration. Moreover, contraction also entails diminished photosynthesis as a consequence of reduced exposure of the zooxanthellae to light. Other possible detrimental effects of the osmoregulatory stress are: cell disruption due to swelling (Muthiga \& Szmant 1987) and a decrease in chlorophyll per algal cell or zooxanthellae loss (bleaching) (e.g. Coles \& Jokiel 1992, Fang et al. 1995). Moreover, corals display enhanced mucus release under stressed conditions, which is a metabolically important carbon sink (Riegl \& Branch 1995). The overall stress in terms of energy loss could thus be considerably greater at 20 and $10 \%$ than what is indicated by the decrease in $P g: R$ ratios.

There may be several explanations for the dominance of Porites lutea and the impoverishment of other coral species at the study area. These include interspecific variation in sediment tolerance (cf. Stafford-Smith 1993), selective grazing by the Diadema setosum urchin on juvenile corals and bioerosion inducing fragmentation-propagation of large P. lutea corals (Sakai et 
al. 1989). Moreover, as shown in this study, different susceptibility to sublethal salinity stress may play an equally significant role.

Although extrapolation of short-term metabolic studies to a daily basis may produce artefacts (cf McCloskey et al. 1978, Jokiel \& Morrissey 1986), we also calculated our values over $24 \mathrm{~h}$ for purposes of comparison with previously published data. Even at the ambient salinity $P g: R$ ratios were below 1 on a $24 \mathrm{~h}$ basis for both species; 0.7 for Porites lutea and 0.9 for Pocillopora damicornis. McCloskey et al. (1978) and Sorokin (1993) suggest normal ranges in the $P g: R$ ratio between 0.8 and 3.5 for Pocillopora and 0.3 and 3.6 for Porites. Even though our results are within these ranges they are still too low for autotrophic maintenance of the corals. To some extent the low values could be due to stress, related to the handling of the specimens. Such an effect is, however, considered to be low as an experiment conducted in situ gave the same results (Nyström et al. 1997).

A more likely explanation of the low $P g: R$ ratios is that the present study site is subjected to siltation combined with eutrophication (Lemay \& Hale 1991), leading to increased respiration due to sedimentation stress (Abdel-Salam \& Porter 1988) and decreased net production as a consequence of reduced light penetration. Although corals are able to photoadapt, it seems that shade adapted corals might excrete more organic carbon and therefore need to supplement autotrophic fixation by ingesting organic carbon from heterotrophic feeding (Falkowski et al. 1990). Thus, reduced light penetration may in the long run favour species relying more upon heterotrophic feeding.

The present study implies that Pocillopora damicornis, when compared to Porites lutea, is 4 times more efficient in heterotrophic feeding on newly hatched Artemia salina. This result is only an estimation of the clearance rate and the feeding rates obtained may therefore not equate to the efficiency at different food availabilities and qualities or different size classes of food particles. Thus, the results must be critically evaluated before being related to the situation in nature. Nonetheless, the relative difference in the feeding rates of the 2 species conforms with similar studies by Sorokin (1993) showing an assimilation rate approximately 4 times higher for $P$. damicornis than Porites annae. On the other hand, $P$. lutea may be better adapted to feeding on bacterioplankton and dissolved organic matter than $P$. damicornis, which has been observed in other corals of the genus Porites ( $P$. annae) (Sorokin 1993). Hence, degree of physiological tolerance to salinity fluctuations and capacity to feed on dissolved and particulate organic matter may be very important structuring factors for the coral community in the innermost part of the Gulf of Thailand.
Acknowledgements. We thank Professor Plamsak Menasvetd, Director of Aquatic Resources Research Institute, and Professors Manuwadi Hungspreugs and Suraphol Sudara, Department of Marine Science, Chulalongkorn University, for making this study possible. We are especially grateful to Dr Ron Johnstone. Department of Zoology, Stockholm University for helpful comments on an earlier version of the manuscript. Finally, we would like to express our gratitude for the financial support given by SWEDMAR (Swedish Centre for Coastal Development and Management of Aquatic Resources) and SIDA (Swedish International Development Cooperation Authority).

\section{LITERATURE CITED}

Abdel-Salam HA, Porter JW (1988) Physiological effects of sediment rejection on photosynthesis and respiration in three Caribbean reef corals. Proc 6th Int Coral Reef Symp 2:285-291

Brown BE (1997a) Disturbances to reefs in recent times. In: Birkeland C (ed) Life and death of coral reefs. Chapman \& Hall, New York, p 354-378

Brown BE (1997b) Adaptations of reef corals to physical environmental stress. Adv Mar Biol 31:221-299

Bythell JC (1988) A total nitrogen and carbon budget for the elkhorn coral Acropora palmata (Lamarck). Proc 6th Int Coral Reef Symp 2:535-540

Chalker BE, Dunlap WC, Oliver JK (1983) Bathymetric adaptation of reef-building corals at Davies Reef, Great Barrier Reef, Australia. II. Light saturation curves for photosynthesis and respiration. J Exp Mar Biol Ecol 73:37-56

Coles SL (1992) Experimental comparison of salinity tolerances of reef corals from the Arabian Gulf and Hawaii. Evidence for hyperhaline adaptation. Proc 7th Int Coral Reef Symp 1:227-234

Coles SL, Joklel PL (1992) Effects of salinity on coral reefs. In: Connell DW, Hawker DW (eds) Pollution in tropical aquatic systems. CRC Press Inc, London, p 147-166

Edmondson CH (1928) The ecology of a Hawaiian coral reef. Bull Bernice P Bishop Mus 45:1

Edmunds PJ, Davies PS (1986) An energy budget for Portes porites. Mar Biol 92:339-347

Endean R (1976) Destruction and recovery of coral reef communities. In: Jones OA, Endean R (eds) Biology and geology of coral reefs, Vol 3. Biology 2. Academic Press, New York, p 215-255

Falkowskı PG, Jokiel PL, Kinzıe RA (1990) Irradiance and corals. In: Dubinsky $Z$ (ed) Ecosystems of the world, Vol 25. Elsevier, New York, p 89-107

Fang LS, Liao CW, Liu MC (1995) Pigment composition in different-colored scleractinian corals before and during the bleaching process. Zool Stud 34:10-17

Grigg RW, Dollar SJ (1990) Natural and anthropogenic disturbance on coral reefs. In: Dubinsky $Z$ (ed) Ecosystems of the world, Vol 25. Elsevier, New York, p 439-452

Harland AD, Brown BE (1989) Metal tolerance in the scleractinian coral Porites lutea. Mar Pollut Bull 20(7):353-357

Johannes RE (1975) Pollution and degradation of coral reef communities. In: Ferguson Wood EJ, Johannes RE (eds) Tropical marine pollution. Elsevier Scientific Publishing, Amsterdam, p 13-50

Jokıel PL, Hunter CL, Taguchi S, Watarai L (1993) Ecological impact of a fresh-water 'reef kill' in Kaneohe Bay, Oahu, Hawail. Coral Reefs 12:177-184

Jokiel PL, Morrissey JI (1986) Influence of size on primary production in the reef coral Pocillopora damicornis and the 
macroalga Acanthophora spicifera. Mar Biol 91:15-26

Kautsky U (1995) Ecosystem processes in coastal areas of the Baltic sea. PhD thesis, Department of Zoology, Stockholm University

Kinsey DW (1983) Standards and performance in coral reef primary production and carbon turnover. In: Barnes DJ (ed) Perspectives on coral reefs. Australian Institute of Marine Science Contribution Number 200, Brian Clouston Publisher, Manuka, p 209-220

Koehn RK, Bayne BL (1989) Towards a physiological and genetical understanding of the energetics of the stress response. Biol J Linn Soc 37:157-171

Lemay M, Hale LZ (1991) A national coral reef strategy for Thailand, Vol 1, Statement of need, Thailand Coastal Resources Management Project, Office of the National Environment Board, University of Rhode Island, and US Agency for International Development

Lindblad C, Kautsky U, André C, Kautsky N, Tedengren M (1989) Functional response of Fucus vesiculosus communities to tributyltin measured in an in situ continuos flowthrough system. Hydrobiologia 188/189:277-283

Loya Y (1976) Recolonisation of Red Sea corals affected by natural catastrophes and man-made perturbations. Ecology $57: 278-289$

Loya Y, Rinkevich B (1980) Effects of oil pollution on coral reef communities. Mar Ecol Prog Ser 3:167-180

McCloskey LR, Wethey DS, Porter JW (1978) Measurement and interpretation of photosynthesis and respiration in reef corals. In: Stoddart DR, Johannes RE (eds) Coral reefs: research methods. Monographs on oceanographic methodology, Vol 5.UNESCO, Paris, p 379-396

Menasveta D, Hongskul $\vee(1988)$ The Gulf of Thailand. In: Postma H, Zijlstra JJ (eds) Ecosystems of the world, Vol 27, Continental shelves (Ecosystem Analyses). Elsevier, Amsterdam, p 363-383

Menasveta P, Navanarasest M, Rungsupa S (1986) Environmental setting of the Gulf of Thailand with special refer-

Editorial responsibility: Otto Kinne,

Oldendorf/Luhe, Germany ence to the Sichang Islands. Galaxea 5:7-13

Muthiga NA, Szmant AM (1987) The effects of salinity stress on the rates of aerobic respiration and photosynthesis in the hermatypic coral Siderastrea siderea. Biol Bull (Woods Hole) 173:539-551

Nakano Y, Tsuchiya M, Rungsupa S, Yamazato K (in press) Influences of severe freshwater flooding dunng the rainy season on the coral community around Khang Khao Island in the Inner Gulf of Thailand. Thai J Aquat Sci

Nystrom M, Moberg F, Tedengren M (1997) Natural and anthropogenic disturbance on reef corals in the Inner Gulf of Thailand; physiological effects of reduced salinity, copper and siltation. Proc 8th Int Coral Reef Symp

Odum HT, Odum EP (1955) Trophic structure and productivity of a windward coral reef community on Eniwetok Atoll. Ecol Monogr 25:291-320

Porter (1976) Autotrophy, heterotrophy and resource partitioning in Caribbean reef-building corals. Am Nat 110;731-742

Riegl B, Branch GM (1995) Effects of sediment on the energy budgets of four scleractinian (Bourne 1900) and five alcyonacean (Lamourox 1816) corals. J Exp Mar Biol Ecol 186: $259-275$

Sakai K, Snidvongs A, Nishihira M (1989) A mapping of a coral-based, non-reefal community at Khang Khao Island, inner part of the Gulf of Thailand: interspecific competition and community structure. Galaxea 8:185-216

Segel LA, Ducklow HW (1982) A theoretical investigation into the influence of sublethal stresses on coral-bacterial ecosystem dynamics. Bull Mar Sci 32(4):919-935

Shaw RG, Mitchell-Olds T (1993) ANOVA for unbalanced data: an overview. Ecology 74(6):1638-1645

Sorokin YI (1993) Coral reef ecology. Ecological studıes, Vol 102. Springer Verlag, Berlin

Stafford-Smith MG (1993) Sediment-rejection of 22 species of Australian scleractinian corals. Mar Biol 115:229-243

Vernberg FJ, Vernberg WB (1972) Environmental physiology of marine animals. Springer Verlag, New York

Submitted: January 20, 1997; Accepted: July 14, 1997

Proofs received from author(s): September 22, 1997 